\title{
Use of a rapid roadside survey to detect potentially invasive plant species along the Garden Route, South Africa
}

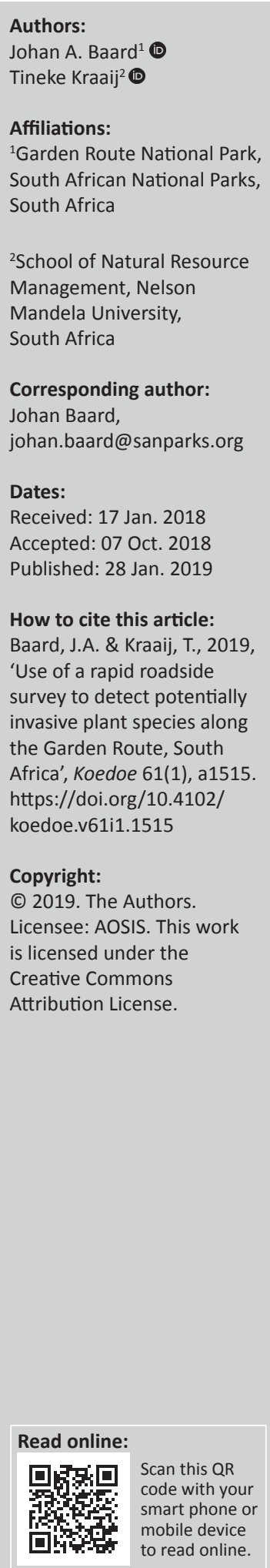

Early detection of emerging or sleeper weeds and monitoring of alien plant invasions forms the foundation of effective invasive alien plant management. Using a rapid roadside survey technique, we aimed to (1) establish a baseline of alien plant distribution and abundance along roads in the Garden Route, South Africa, and (2) identify priority species (particularly sleeper weeds) and priority areas to inform appropriate management action. We surveyed along 530 $\mathrm{km}$ of roads and recorded 109 alien and/or extralimital species across 1942 point locations. Of these, 35 species were considered to be sleeper weeds on account of displaying estimated dispersal distances distinctive of invasive plants and not being listed by the South African Plant Invaders Atlas (SAPIA) or regulated by South African legislation. Roads along natural forest and fynbos vegetation (often within the Garden Route National Park) displayed lower incidences of alien plants than those associated with degraded or transformed land, with roads along farmland associated with the highest incidences of alien plants. Roads in the Southern Cape region had more species and higher densities of alien plants than roads in the Tsitsikamma region, and a few species were exclusive to either.

Conservation implications: Our inventory contributed significant new records and range extensions to SAPIA, while the identified sleeper weeds offered suggestions for species that may be considered for regulation under the National Environmental Management: Biodiversity Act of South Africa. We furthermore provided information to facilitate (1) timely management of emerging invasive alien plants, (2) prioritisation of species and areas for management action, and (3) future monitoring of alien plants in the Garden Route National Park and surrounds.

\section{Introduction}

Worldwide, invasive alien plants are considered to be a major threat to biodiversity and ecosystem services, with the threat deemed to be increasing (Maxwell et al. 2016). Emerging alien species, also called sleeper weeds, are species previously thought to be benign but that may turn invasive; or species that have naturalised but not yet expanded their populations exponentially; or species currently only present in a small area but having the potential to spread widely (Boy \& Witt 2013; Cunningham et al. 2003; Groves 1999; Thuiller et al. 2005; Williams \& West 2000). These species should be closely monitored and assessed for their invasion capacity and timeous decisions made on management actions to be taken. Early detection forms a key component of invasive plant management (Brooks \& Klinger 2009) with rapid response in the form of eradication of single plants or small invasions being among the best investments that can be made (Rejmánek \& Pitcairn 2002). Rapid response is more effective than delayed implementation of alien plant management strategies (Millar, Stephenson \& Stephens 2007; Wilson et al. 2014). Knowledge of the incidence of alien plants and monitoring of changes in their status underpin sound management interventions (Blackburn et al. 2014; Wilson et al. 2014) and as such are mandated by the National Environmental Management: Biodiversity Act (NEMBA, Act 10 of 2004) in South African protected areas (Foxcroft et al. 2017; Wilson et al. 2017).

Roadside surveys are a time- and cost-effective technique that may be used to detect alien plants as they enable relatively rapid collection of substantial quantities of data (Henderson 2007; Henderson \& Musil 1984; Kalwij, Milton \& McGeoch 2008; Shackleton et al. 2017). Roadside surveys have the disadvantage that only plants in the road verge and immediate surrounds can be detected, and they are biased towards larger, conspicuous growth forms (Henderson \& Wilson 2017). In contrast, walking transects are more precise but cover smaller areas per unit of time and effort. Aerial surveys on the other hand are comparatively expensive, and with both aerial surveys 
and remote sensing techniques, spatial resolution is coarse (Vitousek, D'Antonio \& Asner 2010). Detection with these techniques is also limited to the most abundant and largest taxa, which will not enable the recording of a diversity of potentially uncommon species, including sleeper weeds. Roads and roadsides present disturbances that are known to facilitate invasion (Christen \& Matlack 2006; Kalwij et al. 2008; Mortensen et al. 2009), in addition to acting as accidental or unintentional pathways for alien plant dispersal (Pickering \& Mount 2010; Woodward \& Quinn 2011). Roadsides may accordingly be expected to harbour more alien plants than undisturbed habitat. Roadside surveys thus present as a potentially time- and cost-efficient technique to detect alien plants over extensive areas, and they have the additional advantage that they may be combined with other activities (Henderson \& Musil 1984).

Species able to disperse widely have an increased chance of invasion success (Alpert, Bone \& Holzapfel 2000; Kolar \& Lodge 2001; Lloret et al. 2004); accordingly, small seed mass is often an indicator of invasiveness (Rejmánek \& Richardson 1996). Light seeds have the potential to spread much further by wind or other means than larger seeds or fruit (Rejmánek \& Richardson 1996). However, birds are particularly effective long-distance seed vectors, including the seed of larger fruit (Lack \& Evans 2005). Understanding an alien plant species' dispersal strategy and abilities can inform the appropriate approach to, and priority of, its control. Dispersal rates are also used to classify species' invasion status (Pyšek et al. 2004).

Invasive alien plants are considered to be the leading ecological threat to the Garden Route National Park (GRNP) (SANParks 2010) along the southern Cape coast of South Africa. The GRNP is a long and fragmented protected area made up of 29 discontinuous land parcels spreading over an area of $150 \mathrm{~km} \times 35 \mathrm{~km}$. It has a large edge-to-area ratio with various adjacent and protruding land uses, such as urban settlements, agriculture, commercial forestry and conservation (Kraaij, Cowling \& Van Wilgen 2011).
Fragmentation and accessibility associated with a welldeveloped road network within and outside of the GRNP make the park particularly susceptible to the introduction and spread of alien plant species (Alston \& Richardson 2006; Davies \& Sheley 2007; Jodoin et al. 2008; Mortensen et al. 2009; Pickering \& Mount 2010). Baard and Kraaij (2014) compiled an inventory of 244 alien plant species in the GRNP and assigned invasion status to species based on expert opinion, but they did not systematically assess the geographic distribution and abundances of these species in the area.

Using a rapid roadside survey technique, we aimed to (1) establish a baseline of alien plant status along roads in the area of the GRNP that would allow for assessment of future changes in the status of invasions and the effectiveness of management interventions; (2) improve understanding of the spatial distribution of alien plants (including previously unrecorded species) within and outside of the GRNP to inform priority areas for management and future risks; and (3) identify sleeper weeds (i.e. invasive species that have not yet been recognised as such in the region) to facilitate timely management responses to be taken by the GRNP.

\section{Methods Study area}

The study was conducted along roads in and around the GRNP $\left(33.80^{\circ} \mathrm{S} 22.50^{\circ} \mathrm{E}\right.$ to $34.15^{\circ} \mathrm{S} 24.20^{\circ} \mathrm{E} ; 145000$ ha; approximate east-west extent of $150 \mathrm{~km}$ ) between Wilderness Village in the west and Storms River Village in the east, with the Outeniqua and Tsitsikamma Mountains to the north and the Indian Ocean to the south (Figure 1). The area is divided into two regions, the Southern Cape in the west and Tsitsikamma in the east. The pretransformed terrestrial vegetation of the study area was primarily fynbos shrublands and Afrotemperate forest (Vlok, Euston-Brown \& Wolf 2008), much of which is now farmland, commercial timber plantations, alien plant invasions and towns (Wilderness, Sedgefield, Knysna, Plettenberg Bay and Storms River) that surround much of the GRNP (Vromans et al. 2010).

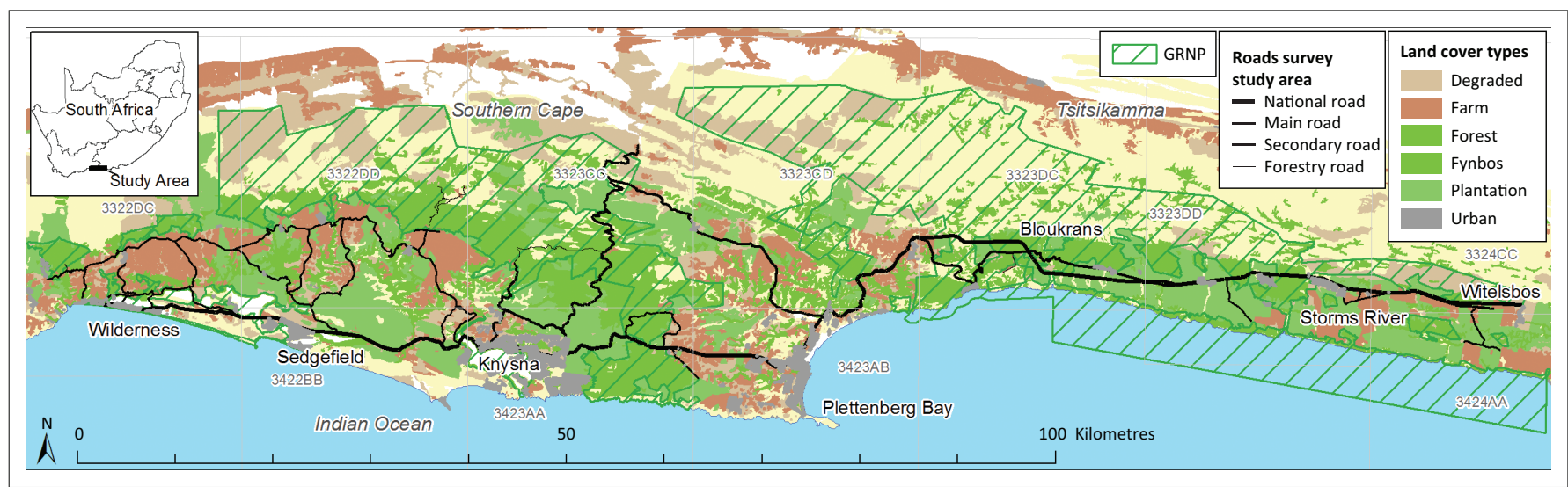

Source: Adapted from Vlok, J.H.J., Euston-Brown, D.I.W. \& Wolf, T., 2008, A vegetation map for the Garden Route Initiative, Unpublished 1:50 000 maps and report supported by CAPE FSP task team and Vromans, D.C., Maree, K.S., Holness, S., Job, N. \& Brown, A.E., 2010, The Garden Route Biodiversity Sector Plan for the George, Knysna and Bitou Municipalities: Supporting land-use planning and decision making in critical biodiversity areas and ecological support areas for sustainable development, Garden Route Initiative and South African National Parks, Knysna, South Africa GNRP, Garden Route National Park.

FIGURE 1: The study area showing the Garden Route National Park, the Southern Cape and Tsitsikamma regions, the roads surveyed and the land cover types adjacent to roads. 
The topography of the study area is characterised by rugged mountains, foothills and coastal plains (altitudinal range $0-1675$ meters above sea level). Deep ravines are cut through the landscape by north-south flowing rivers. The Cape Fold Belt dominates the geology and largely consists of Table Mountain Sandstone with smaller areas of the Bokkeveld Group, Enon Formation, George Granites and Kaaimans Formation (Tham \& Johnson 2006). Aeolian sands deposited during the Quaternary cover the coastal plateau (Illenberger 1996).

Mean annual rainfall ranges between $800 \mathrm{~mm}$ and $1100 \mathrm{~mm}$ and increases from west to east and from south to north with an increase in altitude. Rain falls throughout the year but peaks in spring and autumn (Tyson \& Preston-Whyte 2000). In winter, frost occurs in some areas and snow on the higher mountain peaks. Summers are mildly warm $\left(22^{\circ} \mathrm{C}-25^{\circ} \mathrm{C}\right)$ and winters mild $\left(18^{\circ} \mathrm{C}-21^{\circ} \mathrm{C}\right)$.

\section{Data collection and analysis}

Five hundred and thirty kilometres of roads were surveyed for the presence of alien plants over a period of 11 days during the period December 2016 to February 2017. The total cost of our roadside surveys amounted to approximately R29 000.00 (R22 000.00 for observer salary and R7000.00 for transport). The N2 national road, all main and secondary roads outside of urban areas or villages, and roads accessible to the public inside the park (hereafter 'park roads') were surveyed (Figure 1). Road classification followed the roads' geographical information system (GIS) dataset in SA Explorer Version 3.0 (2004). One driver in a vehicle recorded the presence of all alien plant species visible within or immediately adjacent to road reserves. The national road was tarred, the main and secondary roads tarred or gravelled, and the park roads gravelled. On the N2 speeds of $20 \mathrm{~km} / \mathrm{h}$ $-40 \mathrm{~km} / \mathrm{h}$ or less was maintained compared to only $10 \mathrm{~km} / \mathrm{h}$ $-20 \mathrm{~km} / \mathrm{h}$ on lesser roads.

The focus taxa were alien trees, shrubs, conspicuous creepers (including climbers and scramblers), conspicuous ferns and succulents, whereas inconspicuous herbs (including inconspicuous grasses) were not considered. The most common transformer species in the region - Acacia mearnsii (black wattle), A. melanoxylon (blackwood), A. cyclops (redeye), A. saligna (Port Jackson willow), Solanum mauritianum (bugweed), Pinus (pine) species and Eucalyptus (gum) species were not recorded. Extralimital species (i.e. occurring outside of their native distribution ranges indicated by Manning \& Goldblatt 2012) were also recorded. A Trimble Juno 3B GPS was used with a recording sequence set up in advance, using CyberTracker software. Information recorded included species, locality, abundance, age class, whether the alien was planted, and direction from the road (north, south, east or west). Species identifications were verified against the GRNP's herbarium collection. Species for which matches could not be found were sent for identification by taxonomists at the national (Pretoria) or Compton (Cape Town) herbarium of the South African National Biodiversity
Institute. Nomenclature follows The Plant List (2013). Abundance was recorded as 1, 2,3 or 4 plants or estimated as the number of plants per location $(5-10,11-20,21-50$ or $51-$ 100 ), and for subsequent calculations of plant abundances the median values of abundance class ranges (e.g. 15 for 11-20) were used. Abundances of species occurring in extensive homogenous infestations were estimated for subsampled areas and extrapolated over the total extent of the infestation. In the case of clonal species, abundance values signify stem count estimates. Age classes distinguished were young (i.e. immature), small-mature (i.e. sexually mature plants that were much smaller than the species' potential size) and mature (i.e. sexually mature plants that were close to the species' potential size). This differentiation allowed us to relate young or small-mature plants to their potential parent plants in order to calculate dispersal distances (see below). We noted if plants appeared to have been planted, such as inside fenced properties, in the form of rows or hedges, or visibly pruned inside gardens.

Locations were captured in a GIS (ArcMap 10.4) for further analyses. Point locations were snapped to the road layer and then displaced to the correct side of the road in order to assign each location to an adjacent land cover type. Land cover types (Figure 1) were derived from the vegetation map of Vlok et al. (2008) and the transformation map of Vromans et al. (2010), both mapped at 1:50 000 scale during the mid2000s. Native vegetation in a pristine or near-pristine state (i.e. the 'natural' category of Vromans et al. [2010]) was subdivided into fynbos and forest after the biome classification of Vlok et al. (2008). Non-natural land cover types included degraded (including the categories degraded, heavy alien degraded and alien transformed of Vromans et al. [2010]), plantations (afforested with alien Pinus or Eucalyptus species) and farms (irrigated crop agriculture or pastures, and farm infrastructure), categorised as such by Vromans et al. (2010). We calculated three measures of alien plant incidence: species richness (number of species), species density (number of species expressed per $10 \mathrm{~km}$ of road length) and plant density (number of plants expressed per $10 \mathrm{~km}$ of road length). We compared the incidence of alien plants in terms of these measures between (1) the Southern Cape and Tsitsikamma regions, (2) inside and outside of the GRNP and (3) land cover types.

Dispersal distances were estimated by means of distance analysis in GIS for selected species - largely shrubs and trees that reproduce sexually. Dispersal distances were measured from mature individuals to small-mature or young individuals of the same species between $100 \mathrm{~m}$ and $3 \mathrm{~km}$ from the mature individual. The distances to the 200 closest conspecific plants were calculated in Microsoft Excel, from the GIS-derived data, for each mature plant location of the select species. Dispersal distances were used to assess whether species complied with dispersal rates specified by Pyšek et al. (2004) for a species to be classified as invasive (i.e. plants producing reproductive offspring by seed more than $100 \mathrm{~m}$ from parent plants in less than 50 years). Our approach was aimed at deriving approximations of spread ability 
rather than at proving particular relationships between young and parent plants. To this end, the occurrence of smallmature or young plants (apparently not planted by humans) more than $100 \mathrm{~m}$ away from a potential parent signified spread unaided by humans.

The study area stretched across 11 quarter degree squares (QDSs). We compared our records of alien plant locations per QDS with those of the March 2017 South African Plant Invader Atlas (SAPIA) (Henderson \& Wilson 2017). We also checked whether the alien plant species we recorded were listed as invasive species by NEMBA. In line with the definitions of sleeper weeds referred to earlier, we aimed to identify species that to date have been considered as benign (i.e. absent from SAPIA and NEMBA) but that were showing signs of spread. Accordingly, we identified species as sleeper weeds if a species complied with Criteria 1 and 3, or 2 and 3, of the following: (1) species has not been recorded by SAPIA in the study region; (2) species is not listed by NEMBA; (3) species displayed dispersal distances of $>100 \mathrm{~m}$ and is thus potentially invasive (after Pyšek et al. 2004).

\section{Results}

In this rapid assessment 109 exotic plant species were recorded across 1942 locations (Table 1). Thirty-five of these species were not NEMBA-listed and 35 species have not been recorded by SAPIA for the study area. Importantly, absence of a species from our data does not prove absence of the species from the area, as inconspicuous species and individuals may be overlooked during a rapid survey. The most abundant species by numbers were Nephrolepis cordifolia (sword fern) estimated at 4871 plants, Ammi visnaga (false Queen Anne's lace, toothpick weed) 2766 plants and Lantana camara (lantana) 1333 plants. The highest abundance class used (50-100 plants) likely underestimated numbers of certain species, such as N. cordifolia and L. camara, which may have occurred at abundances of up to 100-500 plants per location, although in the case of clonal plants, abundance values rather signified stem count estimates. The species that occurred at the largest number of locations (indicative of wide distributions) were Acacia elata (pepper tree wattle) at 130 and C. selloana or C. jubata (pampas grass) at 102 locations.

The Southern Cape region had higher alien species richness than the Tsitsikamma region, but given that the former had double the extent of roads, it had lower species density (Table 2). The Southern Cape also exhibited higher alien plant density than Tsitsikamma. Prominent species that were only recorded in the Southern Cape included L. camara, whereas Alnus sp., Liquidambar styraciflua (American storax) and Solanum chrysotrichum (giant devil's fig) were exclusive to the (easternmost part of) Tsitsikamma (Table 1). Some species occurred as a few large disjunct populations throughout the study area, such as Ammi visnaga, which had five large populations, each $2.5 \mathrm{~km}$ to $12.0 \mathrm{~km}$ long.

Alien species richness and plant density were lower inside the GRNP than outside (Table 2). Species density (number of species per unit of road length) was however higher inside the park than outside because of the limited extent of roads inside the park. Species recorded at the largest numbers of locations (i.e. widely distributed) inside the park included Paraserianthes lophantha (stink bean), Melia azedarach (syringa) and Hakea salicifolia (willow hakea), whereas those that were most abundant were N. cordifolia, Sesbania punicea (red sesbania) and L. camara.

Among the five land cover types, alien plants were overrepresented adjacent to farms in terms of species richness, species density and plant abundance (Table 2). Alien species richness and plant density were considerably higher in altered land cover types (degraded, farm and plantation) than in natural vegetation (forest and fynbos). Forest had almost double the alien species richness of fynbos, but lower species densities and plant densities.

The most noticeable addition to SAPIA records for the region was the herb Ammi visnaga, recorded at 74 locations across eight QDSs (Table 1). We recorded Sphaeropteris cooperi (Australian tree fern) in eight QDSs, as opposed to SAPIA's two. Other additions to SAPIA records included Alnus sp., S. chrysotrichum, Banksia ericifolia (heath-leaved banksia) and Cupressus arizonica (Arizona cypress), the latter at eight locations across three QDSs. Ten extralimital species were recorded, the most abundant of which was Tecoma capensis (Cape honeysuckle) in eight QDSs, Dais cotinifolia (pompon tree) and Setaria cf. megaphylla (bush buffalo grass) in three QDSs, Cyperus papyrus (papyrus), Syzygium cordatum (water berry) and Carissa macrocarpa (num-num) in two QDSs, and Erythrina cf. lysistemon (coral tree) and Podocarpus henkelii (Henkel's yellowwood) in one QDS (Table 1). Domestic fruit trees - Prunus persica (peach), Eriobotrya japonica (loquat), Cydonia oblonga (quince), Citrus limon (lemon) and Pyrus communis (pear) - were observed as young plants that appeared to have recruited from seeds. Prunus persica was recorded at 22 locations across seven QDSs and E. japonica at four locations in one QDS.

We identified 35 species as sleeper weeds (i.e. invasive), of which five were extralimital species. Ammi visnaga, Quercus robur (English oak), T. capensis, Corymbia ficifolia (red flowering gum), Syzygium paniculatum (bush cherry), Quercus palustris (pin oak) and Yucca aloifolia (yucca) occurred at the highest densities and were most widely distributed (Table 1). Ten of these species occurred in more than half of the QDSs comprising the study area. Quercus robur occurred in all 11 QDSs and appeared to have dispersed $>100 \mathrm{~m}$ in 31 instances. Large numbers of variously aged young of Quercus acutissima and Q. palustris growing close to the planted parent trees were recorded at Witelsbos in the easternmost part of Tsitsikamma. Such proliferation of Quercus acutissima (sawtooth oak) and Q. palustris was not evident in the Southern Cape. Numerous $Y$. aloifolia seedlings were furthermore observed in the Witelsbos area, whereas in the Southern Cape the species only reproduced vegetatively. Other sleeper weeds 
TABLE 1: Alien and extralimital plant species recorded in the roadside survey and associated information.

\begin{tabular}{|c|c|c|c|c|c|c|c|c|c|c|}
\hline \multirow{3}{*}{$\begin{array}{l}\text { Species } \\
\text { Acacia baileyana }\end{array}$} & \multirow{3}{*}{$\begin{array}{l}\text { Family } \\
\text { Fabaceae }\end{array}$} & \multirow{3}{*}{$\begin{array}{l}\begin{array}{l}\text { Growth } \\
\text { form }\end{array} \\
\text { Tree }\end{array}$} & \multirow{3}{*}{$\begin{array}{c}\text { Sleeper } \\
\text { weed }\end{array}$} & \multirow{3}{*}{$\begin{array}{c}\begin{array}{c}\text { Number of } \\
\text { plants }\end{array} \\
37\end{array}$} & \multirow{2}{*}{\multicolumn{2}{|c|}{$\begin{array}{l}\text { Number of locations } \\
\text { (of which planted) }\end{array}$}} & \multicolumn{2}{|c|}{ Number of QDSs } & \multirow{3}{*}{$\begin{array}{l}\text { NEMBA } \begin{array}{l}\text { or } \\
\text { extralimital }\end{array} \\
3\end{array}$} & \multirow{3}{*}{$\begin{array}{l}\text { Region } \\
T\end{array}$} \\
\hline & & & & & & & \multirow{2}{*}{$\begin{array}{c}\text { Survey } \\
2\end{array}$} & \multirow{2}{*}{$\frac{\text { SAPIA }}{3}$} & & \\
\hline & & & & & 3 & (0) & & & & \\
\hline Acacia decurrens & Fabaceae & Tree & - & 150 & 2 & (0) & 1 & 1 & 2 & SC \\
\hline Acacia elata & Fabaceae & Tree & - & 1243 & 130 & $(22)$ & 10 & 11 & $1 b$ & $S C \& T$ \\
\hline Acacia longifolia & Fabaceae & Tree & - & 215 & 30 & (0) & 6 & 9 & $1 b$ & $S C \& T$ \\
\hline Acacia podalyriifolia & Fabaceae & Tree & - & 296 & 26 & (3) & 5 & 6 & $1 b$ & $S C \& T$ \\
\hline Acacia stricta & Fabaceae & Tree & - & 4 & 1 & (0) & 1 & 5 & $1 \mathrm{a}$ & SC \\
\hline Acer negundo & Sapindaceae & Tree & - & 325 & 17 & (2) & 5 & 1 & 3 & $S C \& T$ \\
\hline Agathis australis & Araucariaceae & Tree & - & 4 & 1 & (1) & 1 & - & Not listed & SC \\
\hline Agave americana & Asparagaceae & Succulent & sw & 46 & 10 & (5) & 5 & 3 & Not listed & SC \\
\hline Agave attenuata & Asparagaceae & Succulent & - & 10 & 2 & (2) & 1 & - & Not listed & SC \\
\hline Agave vivipara & Asparagaceae & Succulent & - & 19 & 2 & (2) & 1 & - & Not listed & SC \\
\hline Ailanthus altissima & Simaroubaceae & Tree & - & 16 & 2 & (0) & 1 & 2 & $1 b$ & SC \\
\hline Alnus sp..$^{\dagger}$ & Betulaceae & Tree & - & 1 & 1 & (0) & 1 & - & Not listed & $T$ \\
\hline Ammi visnaga $a^{1, \dagger}$ & Apiaceae & Herb & sw & 2776 & 74 & (0) & 8 & - & Not listed & SC \& T \\
\hline Anredera cordifolia & Basellaceae & Creeper & - & 134 & 13 & (0) & 5 & 4 & $1 b$ & $S C \& T$ \\
\hline Arundo donax & Poaceae & Graminoid & - & 68 & 5 & (0) & 3 & 11 & $1 b$ & SC \\
\hline Azolla sp. & Azollaceae & Herb & - & 375 & 5 & (0) & 2 & 4 & $1 b$ & SC \\
\hline Banksia integrifolia & Proteaceae & Tree & - & 6 & 2 & (0) & 1 & - & Not listed & SC \\
\hline Callistemon rigidus & Myrtaceae & Shrub & sw & 205 & 9 & (5) & 5 & - & $1 b$ & $S C \& T$ \\
\hline Callistemon viminalis & Myrtaceae & Shrub & - & 58 & 28 & (20) & 8 & 3 & $1 b$ & $S C \& T$ \\
\hline Canna indica & Cannaceae & Herb & - & 158 & 11 & (1) & 7 & 7 & $1 b$ & $S C \& T$ \\
\hline Canna $\times$ generalis & Cannaceae & Herb & - & 17 & 2 & (0) & 2 & 3 & Not listed & SC \\
\hline Carissa macrocarpa & Apocynaceae & Shrub & sw & 31 & 3 & (2) & 2 & - & Extralimital & SC \\
\hline Casuarina equisetifolia & Casuarinaceae & Tree & sw & 149 & 10 & (5) & 6 & - & 2 & SC \& T \\
\hline Cereus jamacaru ${ }^{\dagger}$ & Cactaceae & Succulent & - & 15 & 1 & (1) & 1 & - & $1 b$ & $\mathrm{~T}$ \\
\hline Cestrum laevigatum & Solanaceae & Shrub & - & 559 & 56 & (0) & 6 & 5 & $1 b$ & SC \& T \\
\hline Cinnamomum camphora & Lauraceae & Tree & - & 41 & 15 & (13) & 5 & 1 & $1 b$ & SC \& T \\
\hline Cirsium vulgare & Asteraceae & Herb & - & 235 & 5 & (0) & 2 & 4 & $1 b$ & SC \\
\hline Citrus limon & Rutaceae & Tree & - & 2 & 2 & (1) & 2 & - & Not listed & SC \& T \\
\hline Cortaderia selloana & Poaceae & Graminoid & - & 241 & 102 & (0) & 9 & 11 & $1 b$ & SC \& T \\
\hline Corymbia ficifolia ${ }^{2}$ & Myrtaceae & Tree & sw & 708 & 65 & (47) & 10 & - & Not listed & SC \& T \\
\hline Cotoneaster franchetii & Rosaceae & Tree & - & 31 & 3 & $(2)$ & 2 & 1 & $1 b$ & $S C \& T$ \\
\hline Cupressus arizonica & Cupressaceae & Tree & sw & 34 & 11 & (3) & 4 & - & Not listed & SC \& T \\
\hline Cydonia oblonga ${ }^{\dagger}$ & Rosaceae & Tree & - & 2 & 2 & (1) & 2 & - & Not listed & SC \& T \\
\hline Cyperus papyrus & Cyperaceae & Graminoid & sw & 38 & 3 & (1) & 2 & - & Extralimital & SC \& T \\
\hline Dais cotinifolia & Thymelaeaceae & Tree & - & 3 & 3 & (0) & 3 & - & Extralimital & SC \\
\hline Eriobotrya japonica & Rosaceae & Tree & & 28 & 10 & (6) & 5 & 1 & $1 \mathrm{~b}$ & SC \& T \\
\hline Erythrina cf. lysistemon & Fabaceae & Tree & sw & 3 & 3 & (0) & 1 & - & Extralimital & SC \\
\hline Euphorbia milii & Euphorbiaceae & Succulent & - & 15 & 1 & (0) & 1 & - & Not listed & SC \\
\hline Fraxinus angustifolia & Oleaceae & Tree & - & 9 & 2 & (1) & 1 & 1 & 3 & SC \\
\hline Fuchsia regia & Onagraceae & Creeper & - & 1 & 1 & (1) & 1 & - & Not listed & $\mathrm{T}$ \\
\hline Furcraea foetida & Asparagaceae & Succulent & sw & 214 & 8 & (2) & 1 & - & $1 \mathrm{a}$ & SC \\
\hline Gleditsia triacanthos ${ }^{\dagger}$ & Fabaceae & Tree & - & 10 & 3 & (1) & 1 & 1 & $1 b$ & SC \\
\hline Grevillea robusta & Proteaceae & Tree & - & 163 & 46 & (23) & 9 & 4 & 3 & SC \& T \\
\hline Hakea salicifolia & Proteaceae & Shrub & - & 798 & 62 & (18) & 10 & 4 & $1 b$ & SC \& T \\
\hline Hakea sericea & Proteaceae & Shrub & - & 98 & 13 & (0) & 5 & 11 & $1 b$ & SC \\
\hline Hedera helix ${ }^{\dagger}$ & Araliaceae & Creeper & - & 1 & 1 & (0) & 1 & 1 & 3 & SC \\
\hline Hedychium spp. & Zingiberaceae & Herb & - & 360 & 11 & (3) & 4 & 2 & $1 b$ & $S C \& T$ \\
\hline Homalanthus populifolius & Euphorbiaceae & Shrub & - & 20 & 4 & (0) & 2 & 1 & $1 b$ & SC \& T \\
\hline Hylocereus undatus ${ }^{\dagger}$ & Cactaceae & Succulent & - & 35 & 1 & (1) & 1 & - & 2 & SC \\
\hline Ipomoea cairica & Convolvulaceae & Creeper & - & 15 & 1 & (0) & 1 & - & Extralimital & SC \\
\hline Ipomoea indica & Convolvulaceae & Creeper & - & 15 & 1 & (1) & 1 & 3 & $1 \mathrm{~b}$ & SC \\
\hline Ipomoea purpurea & Convolvulaceae & Creeper & - & 239 & 11 & (0) & 5 & 5 & $1 b$ & SC \\
\hline Jacaranda mimosifolia & Bignoniaceae & Tree & - & 43 & 12 & (11) & 6 & - & Not listed & SC \& T \\
\hline Lantana camara & Verbenaceae & Shrub & - & 1333 & 61 & (0) & 7 & 11 & $1 \mathrm{~b}$ & SC \& T \\
\hline Leptospermum laevigatum & Myrtaceae & Tree & - & 611 & 25 & (3) & 7 & 11 & $1 b$ & $S C \& T$ \\
\hline Liquidambar styraciflua ${ }^{\dagger}$ & Altingiaceae & Tree & - & 1 & 1 & (0) & 1 & - & Not listed & $\mathrm{T}$ \\
\hline Ludwigia palustris & Onagraceae & Herb & sw & 110 & 2 & (0) & 2 & - & Not listed & SC \\
\hline Melia azedarach & Meliaceae & Tree & - & 215 & 97 & (32) & 10 & 11 & $1 b$ & $S C \& T$ \\
\hline Metrosideros excelsa & Myrtaceae & Tree & - & 2 & 2 & $(2)$ & 2 & - & Not listed & SC \\
\hline
\end{tabular}


TABLE 1 (Continues...) Alien and extralimital plant species recorded in the roadside survey and associated information.

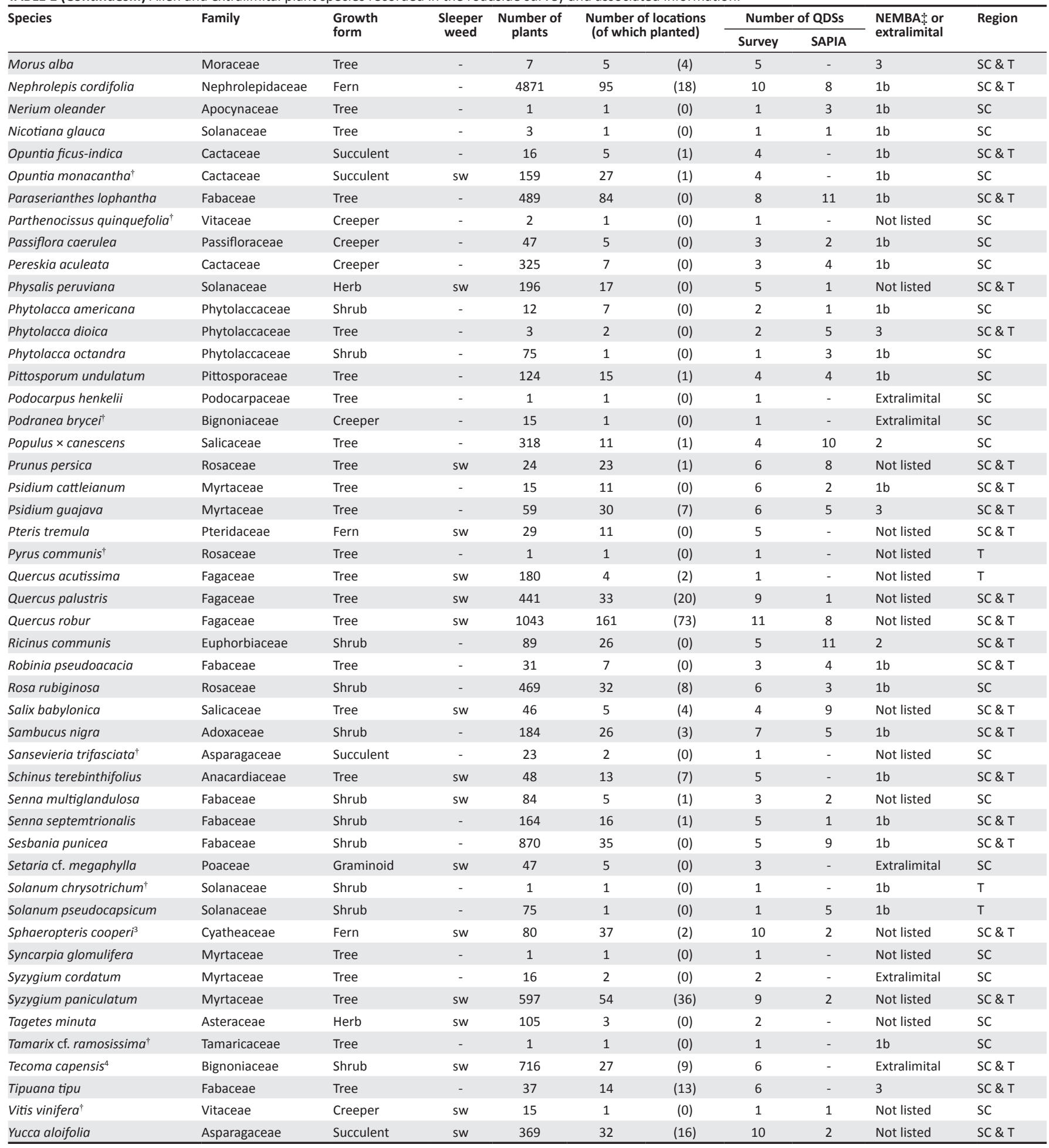

Note: Information shown includes plant growth form, sleeper weed status (sw), total number of plants recorded (including planted individuals), total number of locations recorded (comprising also planted individuals), number of QDSs occupied according to this survey and SAPIA respectively, legal status under NEMBA or whether extralimital, and the region (SC or T) of occurrence.

NEMBA, National Environmental Management: Biodiversity Act; SC, Southern Cape; T, Tsitsikamma; sw, sleeper weed status; SAPIA, South African Plant Invaders Atlas; QDSs, quarter degree squares.

$\dagger$, Species not recorded by Baard and Kraaij (2014).

\$, NEMBA categories: 1 a, priority for control; 1 b, requiring control outside demarcated areas; 2 , permit required; 3 , no further trade or cultivation.

1 , Visnaga daucoides (synonym).

${ }^{2}$, Eucalyptus ficifolia (synonym).

3 , Cyathea cooperi (synonym).

${ }^{4}$, Tecomaria capensis (synonym). 
TABLE 2: Extent of roads and alien plant species richness, species density and plant density compared between regions, inside versus outside of the Garden Route National Park and land cover types.

\begin{tabular}{|c|c|c|c|c|c|}
\hline Variable & $\%$ of surveyed roads & $\begin{array}{c}\text { Species richness } \\
\text { (number of species) }\end{array}$ & $\%$ of all species & $\begin{array}{l}\text { Species density } \\
\text { (number of species per } 10 \mathrm{~km} \text { ) }\end{array}$ & $\begin{array}{l}\text { Plant density } \\
\text { (number of plants per } 10 \mathrm{~km} \text { ) }\end{array}$ \\
\hline \multicolumn{6}{|l|}{ Region } \\
\hline Southern Cape & 68 & 100 & 92 & 2.8 & 526 \\
\hline Tsitsikamma & 32 & 62 & 57 & 3.7 & 360 \\
\hline \multicolumn{6}{|c|}{ Inside vs outside park } \\
\hline Inside & 18 & 53 & 49 & 5.4 & 286 \\
\hline Outside & 82 & 105 & 96 & 2.4 & 517 \\
\hline \multicolumn{6}{|l|}{ Land cover type } \\
\hline Degraded & 34 & 75 & 69 & 4.0 & 445 \\
\hline Farm & 22 & 78 & 72 & 6.4 & 868 \\
\hline Plantation & 23 & 62 & 57 & 4.8 & 360 \\
\hline Forest & 14 & 31 & 28 & 3.9 & 124 \\
\hline Fynbos & 7 & 18 & 17 & 4.8 & 159 \\
\hline
\end{tabular}

identified in this study that were not regarded as invasive by Baard and Kraaij (2014) included Schinus terebinthifolius (Brazilian pepper), Furcraea foetida (Mauritius hemp), Opuntia monacantha (drooping prickly pear), Prunus persica and Quercus acutissima.

Our observations of occurrences of young plants, at distances of $100 \mathrm{~m}-3000 \mathrm{~m}$ from mature or planted conspecific plants, furthermore confirmed the invasive status of $M$. azedarach $(87$ instances), A. elata (26), C. selloana or C. jubata (17), Grevillea robusta (silky oak; 14) and Acacia podalyriifolia (pearl acacia; 4). Species that commonly occurred as planted individuals but showed no sign of spread or regeneration were also worth noting and included the NEMBA-listed species Acacia baileyana (Bailey's wattle), Morus alba (white mulberry), Nerium oleander (oleander) and Phytolacca dioica (ombú), as well as species not listed by NEMBA for this region, Agave attenuata (lion's tail), Jacaranda mimosifolia (jacaranda), Metrosideros excelsa (New Zealand Christmas tree) and Syncarpia glomulifera (turpentine tree).

\section{Discussion}

\section{Spatial distribution of alien plants}

Our comparison of alien plant incidence among land cover types showed that roads associated with natural vegetation (largely coinciding with roads inside the GRNP) had lower species richness and densities of alien plants than those associated with degraded or transformed land (largely coinciding with roads outside the GRNP). Intact natural vegetation, and in particular tall dense vegetation such as forest, is known to present barriers to invasion (Duncan 2011). In addition, narrower verges pertaining to park roads and alien plant management routinely undertaken by the GRNP (Kraaij et al. 2017; Van Wilgen et al. 2016) likely contributed to this finding. Reduced alien plant invasions along roads inside the park (relative to outside) further attest to some level of success achieved by protected area agencies with alien plant management. Roads along farmland had the highest incidence of alien plants and species. Farmland represented the most complete transformation among the land cover types and is associated with relatively high human occupation and regular disturbance, all of which facilitate alien plant invasion (Kalwij et al. 2008; Richardson 2001). Ammi visnaga was most abundant along roads associated with dairy farming and in mowed road verges. Plantations were associated with lesser infestations of alien plants than farmland and other degraded land, possibly because of lower human occupation, better management and awareness of weeds (plantations are mostly certified by the Forestry Stewardship Council; Scotcher 2010) and potential outshading of weeds by tall plantation trees.

Although Tsitsikamma had fewer species and lower densities of alien plants along roads than the Southern Cape, it had higher species density and a few species (e.g. Alnus sp. and S. chrysotrichum) exclusive to the east of the region. Some species furthermore displayed different reproductive behaviour (e.g. Yucca aloifolia apparently reproducing from seed) to that observed in the west. Among other factors, more mesic conditions may facilitate invasion (Richardson et al. 2000) in the eastern Tsitsikamma, and monitoring for new weeds needs to be done regularly. The Southern Cape on the other hand has an expansive road network, transformed landscape and high species richness and densities of alien plants. This region thus faces high propagule pressure and ongoing alien plant management challenges.

\section{Species priorities}

We identified 35 species as sleeper weeds on account of displaying (assumed) dispersal distances distinctive of invasive plants and not having been recorded or listed by SAPIA or NEMBA previously. Effective seed dispersal is notoriously hard to measure (Lack \& Evans 2005), and although it was impossible to prove relationships between young plants and deemed parent plants, the presence of juveniles additionally suggested spread. Our approach of calculating distances between mature and younger plants provided valuable approximations of spread abilities, which could be used to assess invasiveness of species.

Several sleeper weeds occurred widely distributed along roads in the study area. Of these, Ammi visnaga occurred most abundantly and its linear spread along roads suggests that its seeds may be swept along by wind drag of passing vehicles 
(cf. Maslo 2016; Von der Lippe \& Kowarik 2007). Although SAPIA has not recorded this species, a conspecific, Ammi majus (Queen Anne's lace, large bullwort), has been recorded for the study area by Bromilow (2010) and is included in SAPIA in habitat other than fynbos or forest. Ammi visnaga may easily have been overlooked. Ruščić and Nikolić (2011) reported that this species was initially not recognised in a survey of Ammi species in Croatia. Further investigation revealed that this species has been cultivated and used for medicinal purposes for $>120$ years in Croatia. Recently, naturalised or invasive populations of the species were observed in Bosnia and Herzegovina, in natural and disturbed habitat (Maslo 2016). Sphaeropteris cooperi is not listed by NEMBA and was found over a much larger area than indicated by SAPIA. This fern sometimes occurred in colonies but very often as single plants with no apparent parent plant nearby, suggesting long distance dispersal via spores. It also occurred in a range of habitat types, that is, away from roads in pristine closed forest (pers. obs.) and in open pastures. Unless overlooked in previous surveys, $S$. cooperi and $A$. visnaga have spread most markedly compared to SAPIA records. Quercus robur is not NEMBAlisted and has been considered a casual alien in the GRNP (Baard \& Kraaij 2014). However, despite its large, heavy fruits (acorns), we recorded 31 instances of dispersal exceeding $100 \mathrm{~m}$ in addition to reproduction in the immediate surrounds of parent trees and thus consider the species to be invasive. Olrik, Hauser and Kjaer (2012) also noted long distance dispersal in this species. Corymbia ficifolia also occurred widely and abundantly but is not NEMBA-listed and has not been indicated by SAPIA for the study area. Although most of the C. ficifolia we observed occurred as planted avenues, groups or rows of trees (47 localities), the species was unlikely to have been planted at another 18 localities, and young plants close to mature or planted individuals were also observed.

Five sleeper weeds were extralimital species, of which T. capensis, C. macrocarpa and Setaria cf. megaphylla appeared most abundant. The natural range of $T$. capensis is Uitenhage to subtropical Africa and that of C. macrocarpa from Humansdorp to Mozambique (Manning \& Goldblatt 2012). Tecoma capensis, prevalent in horticulture, was often found close to human settlements but also in disturbed lowland fynbos and scrub forest, possibly discarded as garden refuse. Carissa macrocarpa is bird-dispersed and commonly planted in gardens and on road islands. We recorded it in abundance in coastal fynbos between Sedgefield and Wilderness, which corresponds with observations of this species' tolerance for saline coastal soils in Texas (Mink, Singhurst \& Holmes 2015). Setaria megaphylla is indigenous to south-eastern Africa (Van Oudtshoorn 2010) but is considered a weed in commercial pine plantations in South Africa (Rolando \& Little 2009) and naturalised or invasive in parts of the United States (Riefner \& Boyd 2007). Horticultural use of these extralimital species should thus be discouraged outside of their native ranges. Wilson et al. (2014) elucidate the conundrum of extralimital introductions (e.g. practical problems for legislators) and its potential negative consequences, such as its competition with indigenous species through exploitation and habitat change, the introduction of pathogens and parasites, and possible hybridisation.

Our findings on dispersal distances furthermore confirmed the invasive status of bird-dispersed species such as M. azedarach (Voigt, Farwig \& Johnson 2011) and wind dispersed species such as G. robusta (Smith 1998) and C. selloana or C. jubata (Melcher, Bouman \& Cleef 2004; Saura-Mas \& Lloret 2005). In addition to sleeper weeds, a few invasive species (indicated by SAPIA and NEMBA) that currently do not occur inside the GRNP or in low numbers have large numbers of young outside the park (e.g. Acer negundo - ash-leaved maple, A. elata, P. lophantha and $M$. azedarach). These species pose a threat of invasion into the park and should be prioritised for control.

\section{Conclusion}

Relatively low work effort yielded insights into the diversity of alien plants, their spatial distribution and invasive tendencies in the area of the GRNP. The rapid roadside survey provided a baseline dataset of easily detectable alien species and reaffirmed the importance of monitoring to detect sleeper weeds and changes in the status of alien plant populations. Our comprehensive dataset contributed significant new records and range extensions to SAPIA, while the identified sleeper weeds offered suggestions for species to be considered for listing under NEMBA. We furthermore provided information to be used by the GRNP for invasive alien plant management planning and prioritisation of species and areas, as well as future monitoring. If these surveys are to be repeated, it is important that travel speed be replicated as the level of effort affects the precision of observations.

\section{Acknowledgements}

We thank Lesley Henderson for supplying SAPIA data and the South African Weather Service Climate Databank for rainfall data. The South African National Parks and Nelson Mandela University enabled this study. Comments from S. Freitag-Ronaldson, G. Durrheim and R. Scholtz on earlier drafts and suggestions from anonymous reviewers resulted in improvements to the manuscript.

\section{Competing interests}

The authors declare that they have no competing interests with regard to the writing of this article.

\section{Authors' contributions}

J.A.B. and T.K. conceptualised the project. J.A.B. was responsible for data collection, GIS data processing and map, and data analyses. J.A.B. and T.K. wrote the manuscript.

\section{Funding information}

The South African National Parks provided operational cost for this study. 


\section{References}

Alpert, P., Bone, E. \& Holzapfel, C., 2000, 'Invasiveness, invasibility and the role of environmental stress in the spread of non-native plants', Perspectives in Plant Ecology, Evolution and Systematics 3, 52-66. https://doi.org/10.1078/1433-831900004

Alston, K.P. \& Richardson, D.M., 2006, 'The roles of habitat features, disturbance, and distance from putative source populations in structuring alien plant invasions at the urban/wildland interface on the Cape Peninsula, South Africa', Biological Conservation 132, 183-198. https://doi.org/10.1016/j.biocon.2006.03.023

Baard, J. \& Kraaij, T., 2014, 'Alien flora of the Garden Route National Park, South Africa', South African Journal of Botany 94, 51-63. https://doi.org/10.1016/j. sajb.2014.05.010

Blackburn, T.M., Essl, F., Evans, T., Hulme, P.E. \& Jeschke, J.M., 2014, 'A unified classification of alien species based on the magnitude of their environmental impacts', PLoS Biology 12(5), e1001850. https://doi.org/10.1371/journal.pbio. 1001850

Boy, G. \& Witt, A., 2013, Invasive alien plants and their management in Africa, UNEP/ GEF removing barriers to invasive plant management project, CABI Africa.

Bromilow, C., 2010, Problem plants and alien weeds of South Africa, 3rd edn., Briza Publications cc, Arcadia.

Brooks, M.L. \& Klinger, R.C., 2009, 'Practical considerations for early detection monitoring of plant invasions', in Inderjit (ed.), Management of invasive weeds, pp. 9-33, Springer, New York.

Christen, D. \& Matlack, G., 2006, 'The role of roadsides in plant invasions: A demographic approach', Conservation Biology 20, 385-391. https://doi.org/ 10.1111/j.1523-1739.2006.00315.x

Cunningham, D.C., Woldendorp, G., Burgess, M.B. \& Barry, S.C., 2003, Prioritising sleeper weeds for eradication: Selection of species based on potential impacts on agriculture and feasibility of eradication, Bureau of Resource Sciences, Canberra, Australia.

Davies, K.W. \& Sheley, R.L., 2007, 'A conceptual framework for preventing the spatial dispersal of invasive plants', Weed Science 55, 178-184. https://doi.org/10.1614/ WS-06-161

Duncan, R.P., 2011, 'Propagule Pressure', in D. Simberloff \& M. Rejmánek (eds.), Encyclopedia of biological invasions, pp. 561-563, University of California, Berkeley, CA.

Foxcroft, L.C., Van Wilgen, N.J., Baard, J.A. \& Cole, N.S., 2017, 'Biological invasions in South African National Parks', Bothalia 47(2), a2158. https://doi.org/10.4102/abc. South African
v47i2.2158

Groves, R., 1999, 'Sleeper weeds', in A.C. Bishop, M. Boersma \& C.D. Barnes (eds.), Proceedings of the twelfth Australian weeds conference, pp. 632-636, Tasmanian Proceedings of the twe

Henderson, L., 2007, 'Invasive, naturalized and casual alien plants in southern Africa: A summary based on the Southern African Plant Invaders Atlas (SAPIA)', Bothalia 37(2), 215-248. https://doi.org/10.4102/abc.v37i2.322

Henderson, L. \& Musil, K.J., 1984, 'Exotic woody invaders of Transvaal', Bothalia 15(1\&2), 297-313. https://doi.org/10.4102/abc.v15i1/2.1128

Henderson, L. \& Wilson, J.R.U., 2017, 'Changes in the composition and distribution of alien plants in South Africa: An update from the Southern African Plant Invaders Atlas (SAPIA)', Bothalia 47(2), a2172. https://doi.org/10.4102/abc.v47i2.2172

Illenberger, W.K., 1996, 'The geomorphic evolution of the Wilderness dune cordons, South Africa', Quaternary International 33, 11-20. https://doi.org/10.1016/1040 6182(95)00099-2

Jodoin, Y., Lavoie, C., Villeneuve, P., Theriault, M., Beaulieu, J. \& Belzile, F., 2008 'Highways as corridors and habitats for the invasive common reed Phragmites australis in Quebec, Canada', Journal of Applied Ecology 45, 459-466. https://doi. org/10.1111/j.1365-2664.2007.01362.x

Kalwij, J.M., Milton, S.J. \& McGeoch, M.A., 2008, 'Road verges as invasion corridors? A spatial hierarchical test in an arid ecosystem', Landscape Ecology 23, 439-451. https://doi.org/10.1007/s10980-008-9201-3

Kolar, C.S. \& Lodge, D.M., 2001, 'Progress in invasion biology: Predicting invaders', Trends in Ecology \& Evolution 16, 199-204. https://doi.org/10.1016/S0169Trends in Ecolog
$5347(01) 02101-2$

Kraaij, T., Baard, J.A., Rikhotso, D.R., Cole, N.S. \& Van Wilgen, B.W., 2017, 'Assessing the effectiveness of invasive alien plant management in a large fynbos protected area', Bothalia 47(2), a2105. https://doi.org/10.4102/abc.v47i2.2105

Kraaij, T., Cowling, R.M. \& Van Wilgen, B.W., 2011, 'Past approaches and future challenges to the management of fire and invasive alien plants in the new Garden Route National Park', South African Journal of Science 107(9/10), Art. \#633. https://doi.org/10.4102/sajs.v107i9/10.633

Lack, A. \& Evans, D., 2005, Instant notes: Plant biology, 2nd edn., Taylor and Francis, Oxford.

Lloret, F., Médail, F., Brundu, G. \& Hulme, P.E., 2004, 'Local and regional abundance of exotic plant species on Mediterranean islands: Are species traits important?', Global Ecology and Biogeography 13, 37-45. https://doi.org/10.1111/j.1466 882X.2004.00064.X

Manning, J. \& Goldblatt, P., 2012, Plants of the Greater Cape Floristic Region 1: The core Cape Flora, Strelitzia 29, South African National Biodiversity Institute, Pretoria.

Maslo, S., 2016, 'Contribution to the flora of Bosnia \& Herzegovina (New neophytes in the flora of Bosnia and Herzegovina)', Herald of the National Museum of Bosnia and Herzegovina NS 36, 43-61.
Maxwell, S.L., Fuller, R.A., Brooks, T.M. \& Watson, J.E.M., 2016, 'The ravages of guns, nets and bulldozers', Nature 536, 143-145. https://doi.org/10.1038/536143a

Melcher, I.M., Bouman, F. \& Cleef, A.M., 2004, 'Seed atlas of the monocotyledonous genera of the páramo', Flora 199, 286-308. https://doi.org/10.1078/0367-253000157

Millar, C.I., Stephenson, N.L. \& Stephens, S.L., 2007, 'Climate change and forests of the future: Managing in the face of uncertainty', Ecological Applications 17, 2145-2151. https://doi.org/10.1890/06-1715.1

Mink, J.N., Singhurst, J.R. \& Holmes, W.C., 2015, 'Jasminum laurifolium (Oleaceae) adventive in Texas, with observations on alien plant invasions and distribution on the Texas Gulf Coast by passerines', Phytoneuron 36, 1-5.

Mortensen, D.A., Rauschert, E.S.J., Nord, A.N. \& Jones, B.P., 2009, 'Forest roads facilitate the spread of invasive plants', Invasive Plant Science and Management 2, 191-199. https://doi.org/10.1614/IPSM-08-125.1

Olrik, D.C., Hauser, T.P. \& Kjaer, E.D., 2012, 'Natural colonisation of an open area by Quercus robur L.-From where did the vectors disperse the seed?', Scandinavian Journal of Forest Research 27, 350-360. https://doi.org/10.1080/02827581.2011.644318

Pickering, C. \& Mount, A., 2010, 'Do tourists disperse weed seed? A global review of unintentional human-mediated terrestrial seed dispersal on clothing, vehicles
and horses', Journal of Sustainable Tourism 18(2), 239-256. https://doi.org/ and horses', Journal of Sustaind

Pyšek, P., Richardson, D.M., Rejmánek, M., Webster, G.L., Williamson, M. \& Kirschner, J., 2004, 'Alien plants in checklists and floras: Towards better communication J., 2004, 'Alien plants in checklists and floras: Towards better communication
between taxonomists and ecologists', Taxon 53(1), 131-143. https://doi.org/ between taxonomist

Rejmánek, M. \& Pitcairn, M.J., 2002, 'When is eradication of exotic pest plants a realistic goal?', in C.R. Veitch \& M.N. Clout (eds.), Turning the tide: The eradication of invasive species, pp. 249-253, IUCN SSC Invasive Species Specialist Group, Gland.

Rejmánek, M. \& Richardson, D.M., 1996, 'What attributes make some plant species more invasive?', Ecology 77, 1655-1661.

Richardson, D.M., 2001, 'Plant invasions', in Levin, S.A. (ed.), Encyclopedia of biodiversity, vol. 4, pp. 677-688, Academic Press, San Diego, CA.

Richardson, D.M., Bond, W.J., Dean, W.R.J., Higgins, S.I., Midgley, G.F., Milton, S.J.et al., 2000, 'Invasive alien organisms and global change: A South African perspective', in H.A. Mooney \& R.J. Hobbs (eds.), Invasive species in a changing world, pp. 303-349, Island Press, Washington, DC.

Riefner, R.E., Jr. \& Boyd, S., 2007, 'New records of wetland and riparian plants in southern California, with recommendations and additions to the National List of Plant Species that occur in Wetlands', Journal of the Botanical Research Institute of Texas 1, 709-730.

Rolando, C.A. \& Little, K.M., 2009, 'Regional vegetation management standards for commercial pine plantations in South Africa', Southern Forests 71(3), 187-199. https://doi.org/10.2989/SF.2009.71.3.3.915

Ruščić, M. \& Nikolić, T., 2011, 'Ammi visnaga (L.) Lam. (Apiaceae), a new taxon in Croatian flora', Acta Botanica Croatica 70(2), 301-306. https://doi.org/10.2478/ v10184-010-0023-4

SA Explorer Version 3.0, 2004, CD-ROM, Municipal Demarcation Board, Pretoria, South Africa.

SANParks, 2010, The management plan of the Garden Route National Park, Unpublished document, South African National Parks, Knysna, South Africa.

Saura-Mas, S. \& Lloret, F., 2005, 'Wind effects on dispersal patterns of the invasive alien Cortaderia selloana in Mediterranean Wetlands', Acta Oecologica 27, 129-133. https://doi.org/10.1016/j.actao.2004.12.001

Scotcher, J.S.B., 2010, 'Guest editorial. Forest certification in South Africa - the next phase', Southern Forests: A Journal of Forest Science $72(1), 1-4$. https://doi.org/ 10.2989/20702620.2010.484899

Shackleton, R.T., Witt, A.B.R., Nunda, W. \& Richardson, D.M., 2017, 'Chromolaena odorata (Siam weed) in eastern Africa: Distribution and socio-ecological impacts', Biological Invasions 19, 1285-1298. https://doi.org/10.1007/s10530-016-1338-4

Smith, C.W., 1998, 'Hawaiian Alien Plant Studies'. Department of Botany, University of Hawaii, USA, viewed 20 August 2018, from http://www.botany.hawaii.edu/ faculty/cw_smith/aliens.htm.

Tham, A.G. \& Johnson, M.R., 2006. 'The Cape Supergroup', in M.R. Johnson, C.R. Anhaeusser \& R.J. Thomas (eds.), The geology of South Africa, pp. 443-457, Anhaeusser \& R.J. Thomas (eds.)
Council of Geoscience, Pretoria.

The Plant List, 2013, Version 1.1, Published on the Internet, viewed 06 June 2018, from http://www.theplantlist.org/.

Thuiller, W., Richardson, D.M., Pyšek, P., Midgley, G.F., Hughes, G. \& Rouget, M., 2005, 'Niche-based modelling as a tool for predicting the risk of alien plant invasions at a global scale', Global Change Biology 11, 2234-2250. https://doi.org/ 10.1111/j.1365-2486.2005.001018.x

Tyson, P.D. \& Preston-Whyte, R.A., 2000, The weather and climate of southern Africa, Oxford University Press, Cape Town.

Van Oudtshoorn, F., 2010, Guide to grasses of southern Africa, Briza publications, Pretoria, South Africa.

Van Wilgen, B.W., Fill, J.M., Baard, J.A., Cheney, C., Forsyth, A.T. \& Kraaij, T., 2016, 'Historical costs and projected future scenarios for the management of invasive alien plants in protected areas in the Cape Floristic Region', Biological Conservation 200, 168-177. https://doi.org/10.1016/j.biocon.2016.06.008

Vitousek, P.M., D'Antonio, C.M. \& Asner, G.P., 2010, 'Invasions and ecosystems: Vulnerabilities and the contribution of new technologies', in D.M. Richardson (ed.), Fifty years of invasion ecology: The legacy of Charles Elton, pp. 227-288, Wiley-Blackwell, Sussex. 
Vlok, J.H.J., Euston-Brown, D.I.W. \& Wolf, T., 2008, A vegetation map for the Garden Route Initiative, Unpublished 1:50 000 maps and report supported by CAPE FSP task team.

Voigt, F.A., Farwig, N. \& Johnson, S.D., 2011, 'Interactions between the invasive tree Melia azedarach (Meliaceae) and native frugivores in South Africa', Journal of Tropical Ecology 27, 355-363. https://doi.org/10.1017/\$0266467410000702

Von der Lippe, M. \& Kowarik, I., 2007, 'Long-distance dispersal of plants by vehicles as a driver of plant invasions', Conservation Biology 21(4), 986-996. https://doi. org/10.1111/j.1523-1739.2007.00722.x

Vromans, D.C., Maree, K.S., Holness, S., Job, N. \& Brown, A.E., 2010, The Garden Route Biodiversity Sector Plan for the George, Knysna and Bitou Municipalities: Supporting land-use planning and decision making in critical biodiversity areas and ecological support areas for sustainable development, Garden Route Initiative and South African National Parks, Knysna, South Africa.
Williams, J.A. \& West, C.J., 2000, 'Environmental weeds in Australia and New Zealand: Issues and approaches to management', Austral Ecology 25, 425-444. https://doi. org/10.1046/j.1442-9993.2000.01081.x

Wilson, J.R., Gaertner, M., Griffiths, C.L., Kotzé, I., Le Maitre, D.C. \& Marr, S.M., 2014 'Biological invasions in the Cape Floristic Region: History, current patterns, impacts, and management challenges', in N. Allsopp, J.F. Colville \& G.A. Verboom (eds.) Fynbos: Ecology, evolution, and conservation of a megadiverse region, $\mathrm{pp}$. 273-298, Oxford University Press, Oxford.

Wilson, J.R.U., Gaertner, M., Richardson, D.M. \& Van Wilgen, B.W., 2017, 'Contributions to the National Status Report on Biological Invasions in South Africa', Bothalia 47(2), a2207. https://doi.org/10.4102/abc.v47i2.2207

Wilson, J.R., Panetta, D.F. \& Lindgren, C., 2017, Detecting and responding to alien plant incursions, Cambridge University Press, Cambridge, UK.

Woodward, S.L. \& Quinn, J.A., 2011, Encyclopedia of invasive species: From Africanized honey bees to zebra mussels, ABC-CLIO, Santa Barbara, CA. 